\title{
Диференційований підхід у виборі методу артропластики при медіальному гонартрозі (огляд літератури)
}

\author{
П.М.Жук, А.М. Шаммо, В.О. Мовчанюк \\ Вінницький національний медичний університет ім. М.І. Пирогова, Вінниця, Україна
}

Анотація. Мета: проаналізувати переваги і недоліки використання монокондилярного та тотального ендопротезування колінного суглоба при медіальному гонартрозі, визначити наявні диференційні критерії вибору методу артропластики з урахуванням персоніфікованих факторів пацієнта. Результати. Аналіз даних сучасної літератури не дозволив визначити чіткі диференційні критерії вибору оптимального методу артропластики при медіальному гонартрозі з урахуванням персоніфікованих факторів пацієнта. Методика монокондилярного ендопротезування колінного суглоба пов'язана з кращими функціональними результатами, нижчою частотою ускладнень, швидшим одужанням та більшою задоволеністю пацієнтів. Окрім того, відсутні переконливі твердження щодо статистично значущої відмінності у частоті ревізій чи довговічності імплантатів, які довгий час вважалися суттєвими перевагами тотального ендопротезування колінного суглоба. Висновок. У зв'язку із вдосконаленням хірургічної техніки та більшою доступністю у виборі імплантатів монокондилярне ендопротезування колінного суглоба $€$ доведено ефективним методом лікування ізольованого медіального гонартрозу.

Ключові слова: монокондилярне ендопротезування, тотальне ендопротезування, колінний суглоб, гонартроз.

\section{Вступ}

Гонартроз - поняття, яке об'єднує мультифакторіальну, гетерогенну групу захворювань 3 подібними біологічними, морфологічними, клінічними проявами, в основі яких лежить ураження всіх структур колінного суглоба (КС) - суглобового хряща, субхондральної кістки, синовіальної оболонки, зв'язок, капсули та навколосуглобових м'язів [1, 2].

Симптоматичний гонартроз відмічають у $13 \%$ жінок і 10\% чоловіків віком $>60$ років. Ризик розвитку симптоматичного остеоартрозу (ОА) КС протягом життя становить 50\% [1]. Згідно з результатами багатоцентрового епідеміологічного дослідження з великою вибіркою поширеність ОА КС в осіб середнього та літнього віку стрімко зростає [3]. Крім того, прогресивне старіння населення планети та бажання людей покращити якість життя, включаючи мобільність, зумовлюють необхідність пошуку ефективних рішень проблеми [4].

3 морфологічної точки зору, дегенеративний процес при гонартрозі охоплює весь КС, включаючи медіальний, латеральний та надколінно-стегновий відділи [1, 2]. Однак 30-47\% пацієнтів із симптоматичним ОА КС мають прояви дегенеративного процесу лише в одному відділі суглоба [5, 6]. Оскільки медіальний відділ КС змінюється при русі менше, ніж латеральний або патело-феморальний, дегенеративні зміни уражують його в першу чергу. Дегенеративно-дистрофічні зміни медіального відділу КС наявні у кожного 2-го хворого з ОА, навіть на початкових етапах захворювання [5].

Лікування ОА медіального відділу КС спрямоване на зменшення вираженості болю, відновлення функції та покращення якості життя хворих в цілому [3]. Запропоновано різні хірургічні підходи для вирішення цього завдання, наприклад проксимальна остеотомія великогомілкової кістки, дистальна остеотомія стегнової кістки, монокондилярне (МЕП) та тотальне ендопротезування (ТЕП) КС [4]. Вибір методу лікування здійснюють відповідно до віку, рівня активності пацієнта, клінічного перебігу захворювання та анатомічних особливостей КС [7]. Основними варіантами хірургічного лікування медіального гонартрозу $€$ МЕП та ТЕП КС [3]. Однак питання вибору оптимального варіанту ендопротезування досі залишається дискусійним [8, 9].

Мета: проаналізувати переваги і недоліки використання МЕП та ТЕП КС при медіальному гонартрозі, визначити наявні диференційні критерії вибору методу артропластики з урахуванням персоніфікованих факторів пацієнта.

\section{Результати огляду літературних джерел}

Основними найбільш ефективними та доступними методами в лікуванні ОА КС з переважним ураженням медіального відділу $\in$ MEП та TЕП $[2,6]$.
ТЕП довгий час вважали золотим стандартом оперативного втручання при артрозі КС, в тому числі при ізольованому ураженні медіального відділу суглоба, завдяки доведеній надійності, довговічності та ефективності в зменшенні вираженості болю та відновленні функції, і на даний час багато пацієнтів з ізольованим медіальним гонартрозом на пізніх стадіях дегенеративного процесу, які не отримували лікування на попередніх етапах захворювання, $є$ кандидатами для ТЕП КС [1, 5, 7, 9].

У зв'язку з широким впровадженням методики МЕПу практику вибір оптимального варіанту ендопротезування при ізольованому медіальному ОА КС став питанням численних дебатів.

Перевагами МЕП порівняно з ТЕП $є$ збереження кісткової тканини стегнової та великогомілкової кісток, зменшення інтраопераційної та післяопераційної крововтрати, нижча інтенсивність болю в післяопераційний період та менший період перебування в стаціонарі $[6,10,11]$. Порівняно з ТЕП методика МЕП дозволяє зберегти цілісність передньої та задньої хрестоподібних зв'язок, що зумовлює збереження суб'єктивного відчуття природного коліна та природної біомеханіки суглоба [9, 12-14]. 3 точки зору відновлення функції, методика МЕП дозволяє забезпечити більший обсяг рухів, нижчу частоту ригідності суглоба, легше відновлення та меншу потребу в реабілітації. Крім того, нижча загальна вартість МЕП $\epsilon$ додатковою перевагою процедури $[5,10,12,15]$. Згідно з результатами когортних досліджень та даних опублікованих клінічних випадків науковці доводять нижчу частоту ранніх післяопераційних ускладнень, летальність $[6,7,13,14]$ та більшу задоволеність хворих $[5,6,10]$ після МЕП порівняно з ТЕП. В той самий час згідно з даними більшості національних реєстрів частота ревізій при МЕП зазвичай вдвічі перевищує аналогічний показник після ТЕП. Тож вибір між МЕП та ТЕП в лікуванні ізольованого медіального ОА КС $€$ складним завданням як для ортопеда, так і для пацієнта.

Згідно з попередніми даними літератури МЕП вважали кращим методом для тих, хто намагався підтримати натуральну механіку (кінематику) суглоба, зберегти кісткову тканину та створити передумови для подальшого проведення повторного хірургічного втручання у разі необхідності. У зв'язку з цим раніше методику частіше рекомендували молодим активним пацієнтам, яким, як очікується, протягом життя буде необхідним проведення ревізійного ендопротезування [16]. У сучасних умовах очікувана тривалість життя зростає, а тому довговічність імплантату та частота ревізій стають важливими факторами при виборі методики лікування.

Класичними показаннями до МЕП $\epsilon$ медіальний гонартроз зі збереженим згинанням $\geq 90^{\circ}$, відсутність ураження передньої або задньої схрещених зв'язок, згинальна контрактура не більше $10^{\circ}$, варусна деформація не більше $5^{\circ}$ та відсутність ожиріння [6, 7]. Про- 
тягом останніх років показання до МЕП значно розширилися. Зараз методика МЕП рекомендована як молодим пацієнтам, так і пацієнтам віком $>75$ років $[3,10]$. Переглянуто погляди і щодо проведення процедури у пацієнтів з пошкодженнями передньої схрещеної зв'язки, а також з ожирінням [6].

Таким чином, в сучасній літературі відсутні чіткі критерії вибору оптимального методу ендопротезування при медіальному гонартрозі, тобто вибір методу у більшості випадків здійснюється на розсуд лікаря. Як правило, ортопеди використовують одну конкретну форму ендопротезування на основі їх попередньої підготовки, індивідуальних уподобань та клінічного досвіду [1]. Однак рішення щодо вибору типу втручання має бути обґрунтованим на основі клінічних даних з урахуванням індивідуальних потреб пацієнта та наявних персоніфікованих факторів [8,9].

У літературі бракує доказів, які 6 дозволяли однозначно оцінити одну процедуру як кращу за іншу. Так, деякі ортопеди обґрунтовують переваги методики МЕП, в той час як інші наполягають виключно на тотальній заміні суглоба. Обидва підходи мають право на існування, оскільки $\epsilon$ науково підтвердженими [1, 3]. Зважаючи на підвищення попиту у виконанні ендопротезування КС, особливий інтерес викликає вибір методики, яка була б найбільш ефективною.

Зазначимо, що методика МЕП порівняно з ТЕП $\epsilon$ менш доступною у зв'язку з технічними труднощами, обмеженим досвідом чи обізнаністю щодо процедури серед лікарів: лише деякі ортопеди можуть запропонувати пацієнтам цей варіант лікування [7, 8]. Так, частота МЕП у складі загальної первинної артропластики КС не перевищує $10 \%$, хоча близько $50 \%$ пацієнтів $\epsilon$ потенційними кандидатами для виконання одновиросткового ендопротезування [11]. TEП, навпаки, $є$ широко визнаним, надійним, ефективним і доступним хірургічним методом для пацієнтів з термінальною стадією ОА, який спрямований на зменшення вираженості болю, відновлення функцій та покращення показників якості життя $[9,11]$. Незважаючи на ці позитивні ефекти ТЕП, 17-19\% пацієнтів залишаються незадоволеними втручанням [8].

Протягом останніх років згідно з даними національних реєстрів зафіксовано зростання частоти проведення МЕП у більшості розвинених країн світу. У Новій Зеландії, згідно з NZOA Joint Registry (NZJR), частка виконання МЕПу 2020 р. становила 11,6\% [17]. Стрімке зростання у проведенні втручання з 211 у 2019 р. до 1245 у 2020 р. пояснюється обмеженнями, зумовленими пандемією COVID-19. У річному звіті RIPO (Register of Orthopaedic Prosthetic Implants) за 2018 р. в Італії відзначається збільшення частки МЕП з 10,1\% у 2014 р. до 12,0\% у 2018 р. [18, 19]. Згідно із звітом Австралійського об'єднаного реєстру використання МЕП зросло з 5,1\% від усіх замін КС в 2016 р. до 6,2\% у 2017 р. Стрімке підвищення частоти виконання МЕП протягом останніх років відмічають у Великобританії та Північній Америці. Частота виконання МЕП у Сполученому Королівстві зросла більше ніж у 6 разів в період 2003-2012 рр. Зараз частка МЕП становить близько 9\% усіх замін КС у Великобританії. У США відмічали подібне 6-кратне збільшення виконання МЕП при гонартрозі протягом останніх років $[3,8,10]$.

За останнє десятиліття виявлено стрімке зростання інтересу до застосування МЕП в лікуванні ізольованого медіального ОА КС. Однак ортопеди у більшості випадків надають перевагу ТЕ, керуючись досвідом використання методики та даними щодо високої частоти ревізій при МЕП, про які повідомляли у попередніх дослідженнях. Незважаючи на суттєві переваги методики МЕП, деякі хірурги продовжують дотримуватися традиційних застарілих поглядів та побоювань щодо високої частоти ревізій, необхідності повторних втручань, розглядаючи цю методику лише як тимчасову процедуру, яку не рекомендують пацієнтам віком >60 років [20]. Хоча саме у пацієнтів старшого віку методика МЕП $\epsilon$ хорошою альтернативою ТЕП у зв'язку з їі меншою інвазивністю, нижчим ризиком ускладнень, швидшою та кращою функціональною мобільністю пацієнтів старшого віку.

Ефективність методики МЕП у пацієнтів старшого віку підтверджена у дослідженні H. Siman та співавторів (2017), де на основі ретроспективного аналізу даних реєстрів порівнювали віддалені результатИ МЕП та ТЕП серед пацієнтів віком $>75$ років [10]. До груп порівняння включено результати 1356 первинних ТЕП та 126 пер- винних МЕП. Встановлено низьку частоту періопераційних ускладнень та ревізій, які достовірно не відрізнялися від показників, отриманих у групі хворих, яким виконували ТЕП. Автори стверджують, що завдяки менш інвазивному характеру пацієнти віком $>75$ років після МЕП здатні швидше почати відновлення та профілактувати ряд ускладнень порівняно з тими, кому виконували ТЕП. Тож дослідники рекомендують застосовувати МЕП як варіант лікування медіального гонартрозу у пацієнтів літнього віку. M. Fabre-Aubrespy та співавтори (2016) порівнювали результати МЕП та ТЕП у пацієнтів віком $>50$ років з ізольованим медіальним гонартрозом [11]. Підтверджено ефективність методики та менший термін перебування в стаціонарі, меншу післяопераційну крововтрату, меншу кількість трансфузій та більший обсяг рухів у групі осіб, в яких застосовували МЕП.

Ще однією суттєвою перевагою методики МЕП $\epsilon$ нижчий ризик розвитку ускладнень, пов'язаних з втручанням. Як відомо, ризик виникнення ускладнень у пацієнтів після МЕП нижче на 60\% порівняно з тими, які перенесли ТЕП $[8,12]$. Аналогічні результати, які підтверджують вищу частоту ранніх післяопераційних ускладнень при ТЕП у короткострокових результатах (з періодом спостереження до 5 років), отримані у дослідженні A. Arirachakaran та співавторів (2015) [20]. Проте останні повідомляють і про вищу частоту ревізій при МЕП.

У великому дослідженні A.D. Liddle та співавтори (2014) порівнювали результати проведених 25334 МЕП та 75996 ТЕП. Виявлено, що загальні показники ревізії були вищими в групі осіб, в яких застосовували МЕП, тоді як смертність, тривалість стаціонарного лікування, частота ускладнень (включаючи тромбоемболію, інфаркт міокарда та інсульт) та частота повторної госпіталізації були вищими в когорті пацієнтів, які перенесли ТЕП. Дослідники дійшли вИсновку, що якби 100 пацієнтам, які перенесли ТЕП, виконали МЕП, в результаті було б приблизно на 1 випадок смерті менше та на 3 повторні операції більше протягом перших 4 років після операції [21].

Існують повідомлення про нижчу частоту венозного тромбозу при МЕП порівняно з ТЕП [8]. Однак у масштабному дослідженні N.M. Brown та співавторів (2012) не встановлено статистично значущої відмінності у частоті тромбоемболічних ускладнень у групах пацієнтів, в яких застосовували МЕП та ТЕП протягом 5-річного спостереження [29].

Протягом тривалого часу високу частоту ревізій вважали найбільш суттєвим недоліком МЕП, який при виборі зумовлював надання переваги ТЕП. Однак погляди щодо частоти ревізій зазнали суттєвих змін протягом останніх років. $Є$ повідомлення, що показники виживання ендопротезу при МЕП становили 95 та 90\% протягом 5 і 10 років відповідно [8]. В аналізі віддалених результатів лікування у 432 пацієнтів з медіальним гонартрозом, в яких застосовували МЕП, рівень виживання імплантату становив 97,5\%. Середній період спостереження становив 5,7 року [8, 23]. Подібні результати підтверджено у дослідженні J.R.H. Foran та співавторів (2013), які продемонстрували високі рівні виживання ендопротезу - 98, 93 і $90 \%$ протягом 10 , 15 і 20 років відповідно. Статистично значущої різниці у частоті 5-річного виживання ендопротезу у групах МЕП та ТЕП не доведено [30].

Цікавими $\epsilon$ нечисленні публікації, в яких порівнювали ефективність методик МЕП та ТЕП в одних і тих самих пацієнтів [6]. Порівняння різних імплантатів у одного пацієнта дозволяє уникнути відмінностей щодо способу його життя, наприклад функціональної активності або тютюнопаління, фізичних особливостей, тобто персоніфікованих факторів, які можуть впливати на функцію ендопротезу. Можна стверджувати, що цей дизайн забезпечує ідеальну групу для порівняльного аналізу.

Так, у дослідженні U.G. Longo та співавторів (2015), де порівнювали результати МЕП та ТЕП в одних і тих самих пацієнтів, доведено достовірно кращі післяопераційні показники обсягу рухів, клінічні результати згідно з KSS (Knee Society Score) та показники функції в обох групах порівняно з вихідними даними. У групі хворих, яким виконували МЕП, доведено достовірно кращі значення обсягу рухів у післяопераційний період порівняно з показниками хворих, яким виконали ТЕП, відмінностей щодо результатів KSS та функціонального балу не виявлено. Автори повідомили про незначну перевагу ТЕП щодо виживання (100 проти 94\%) із середнім періодом 
спостереження 57,2 міс, однак відмінність не була статистично значущою $(\mathrm{p}=0,09)$. Суттєве підвищення рівня виживання ендопротезів при МЕП за останні два десятиліття пов'язують з удосконаленнями конструкції імплантатів та оперативної техніки [6].

Доведеним важливим фактором у досягненні успішних результатів $\epsilon$ досвід хірурга. Проведення мінімально інвазивного втручання потребує від ортопеда ретельного дотримання усіх вимог хірургічної техніки, тому недостатній досвід може призвести до вищої частоти технічних помилок і ранніх негативних наслідків лікування $[3,7,12]$. Попередні дослідження повідомляють про більш високий рівень незадовільних результатів у центрах з невеликою кількістю виконання МЕП (<10 на рік), ніж з великою частотою проведення втручань даного типу. Також виявлено, що кількість проведених операцій значно впливає на частоту ревізій у когорті осіб, в яких застосовували методику МЕП. У ортопедів, які виконували < 10 процедур МЕП на рік, частота виживання імплантатів через 8 років становила 87,9\%, натомість у лікарів, які виконували >30 операцій МЕП на рік, цей показник становив 92,4\% [5, 21].

У метааналізі M. Deng та співавторів (2021) доведено, що пацієнти з медіальним гонартрозом, яким виконували МЕП, досягли кращих клінічних результатів, включаючи показники функціонального відновлення та фізичного здоров'я, мали менш виражений больовий синдром та нижчу частоту ускладнень, ніж пацієнти в групі ТЕП. Автори вказують на відсутність статистично значущих відмінностей у частоті післяопераційної ревізії при МЕП та ТЕП протягом 5-річного спостереження [8].

Основою для формування твердження щодо високої частоти ревізій у більшості випадків $\epsilon$ дані, відображені у національних реєстрах, а не результати рандомізованих клінічних досліджень. Тому, аналізуючи ці показники, необхідно враховувати, що кожен з реєстрів має власні індивідуальні класифікації щодо визначення поняття ревізії. Наприклад, прогресування ОА контрлатерального відділу суглоба як причина ревізії не $\epsilon$ наслідком негативного впливу імплантату чи недоліком техніки MEП, а швидше зумовлено неправильним виконанням методики або $є$ відображенням етапності у лікуванні захворювання $[13,15]$. Додатковим чинником вищої частоти ревізій при МЕП може бути помилкове визначення показань до втручання [14, 24].

Зазначимо, що дані стосовно високої частоти ревізій відображені переважно в більш ранніх дослідженнях, коли існували певні обмеження у виборі імплантатів, технічні недосконалості методики, які могли бути причинами високого рівня ревізій при МЕП. В опублікованих дослідженнях існує консенсус, що хірургічна майстерність обернено пропорційна до частоти ревізій при МЕП [8]. Крім того, дані реєстрів не включають інформацію щодо клінічних результатів лікування, задоволеності пацієнтів, досвіду хірурга, рівня лікувального закладу та системи охорони здоров'я, не визначають даних щодо повторної операції, а також не включають інформацію щодо причини повторного втручання.

Згідно з результатами дослідження J.H. Newman та співавторів (1998), в якому порівнювали результати ТЕП та МЕП 102 КС, нижчі показники больового синдрому та кращу функціональну спроможність суглобів протягом 5 років спостерігали у хворих після МЕП, у більш віддалений період достовірної відмінності за розглянутими показниками не відмічено [31]. Відсутність достовірної різниці у частоті ревізій при порівнянні ефективності методик підтвердили D.S. Casper та співавтори (2019), які відмічали кращі функціональні показники після МЕП та невелику перевагу в підшкалі симптомів у пацієнтів, які перенесли ТЕП, без відмінностей у частоті ускладнень або ревізій в обох групах. У пацієнтів, яким виконували ТЕП, як правило, відмічали значно сильніший біль перед операцією, що пояснює значно більше зменшення вираженості симптомів у них порівняно з пацієнтами, яким виконували МЕП. У дослідженні доведено еквівалентну задоволеність від проведеного втручання в обох групах, однак очікування від втручання були більш виправданими у пацієнтів після МЕП, ніж у випадку ТЕП [5].

Задоволення пацієнта від проведеного втручання в сучасних умовах розглядається як важливий фактор в аналізі ефективності лікування. Рівень задоволення пацієнта операцією тісно пов'язаний з рівнем його очікувань в передопераційний період. Незважаючи на досягнення в сфері дизайну імплантатів, хірургічної техніки та догляду за пацієнтами, майже $30 \%$ пацієнтів вважають, що їх очікування не виправдалися після ТЕП $[3,5,6]$.

Для характеристики задоволення пацієнта проведеним втручанням використовують опитувальник Forgotten Joint Score (FJS)-12, що дозволяє оцінити спроможність хворого забути про імплантований штучний суглоб в післяопераційний період. У ряді досліджень повідомляють про кращі значення FJS-12 у пацієнтів після МЕП порівняно з результатами після ТЕП [12, 22, 25, 26]. Натомість E. Thienpont та співавтори (2014) протягом 2-річного періоду спостереження не виявили суттєвої різниці між значеннями FJS-12 з урахуванням типу ендопротезування KC [32]. S.K. Tripathy та співавтори (2021) у метааналізі, який включав результати 105 досліджень щодо оцінки усвідомленості суглобів після МЕП та ТЕП, дійшли висновку, що пацієнти з МЕП більш схильні забувати про свій штучний суглоб у повсякденному житті порівняно з пацієнтами, які перенесли ТЕП. Показники FJS-12, які оцінювали через 6 міс, 1 рік та 2 роки у групі хворих, яким виконували МЕП, були достовірно кращими порівняно з показниками в групі хворих, яким виконували ТЕП, на всіх етапах визначення [12]. На думку Ү. Ніуата та співавторів (2016), усвідомлення штучного суглоба пов'язано з вираженістю больового синдрому та силою чотириголового м'яза [27]. Менша травматизація тканин під час МЕП i, зокрема, збереження чотириголового м'яза зумовлюють раннє досягнення більш високого FJS-12 у пацієнтів після МЕП. Точні механізми збереження більш природного відчуття суглоба після МЕП порівняно з результатами ТЕП залишаються не до кінця відомими. Вважають, що мінімальна травматизація кісткової тканини та навколишніх м'яких тканин зі збереженням схрещених зв'язок і чотириголового м'яза, ймовірно, дозволяють зберегти пропріоцептивні волокна $[12,22,25,27]$. Натомість збереження пропріоцептивної м'язово-суглобової чутливості у комплексі з відновленням природної «додегенеративної» механічної осі нижньої кінцівки дозволяють відновити відчуття природного суглоба після МЕП [28].

У численних дослідженнях доведено, що у пацієнтів, яким виконували МЕП, рівень задоволення операцією достовірно вище порівняно з хворими, в яких застосовували ТЕП, що зумовлено перевагами методики МЕП. Незважаючи на це, у 25-47\% пацієнтів із артрозом медіального відділу КС, які $\epsilon$ кандидатами для МЕП, застосовують методику ТЕП $[5,8,12]$.

\section{ВИСНОВКИ}

Таким чином, вибір типу ендопротезування при ОА КС 3 переважним ураженням медіального відділу залишається складним завданням. Аналіз даних сучасної літератури не дозволив визначити чіткі диференційні критерії вибору методу артропластики при медіальному гонартрозі з урахуванням персоніфікованих факторів пацієнта.

Хоча дані попередньої літератури демонстрували певні передбачувані переваги підходу ТЕП, зокрема щодо довговічності імплантатів та частоти ревізій, підсумовуючи результати сучасних досліджень, можна стверджувати про кращі функціональні результати, нижчу частоту ускладнень, швидше одужання та більшу задоволеність пацієнтів після МЕП без статистично значущої відмінності щодо частоти ревізій.

У зв'язку з вдосконаленням хірургічної техніки, можливістю застосування роботизованих технологій та більшої доступності у виборі імплантатів у наш час МЕП $\epsilon$ доведено ефективним методом лікування ізольованого медіального гонартрозу.

\section{Список використаної літератури}

1. Шуба В.Й. (2016) Остеоартроз: рання діагностика та лікування. Укр. мед. часопис, 1(111): www.umj.com.ua/article/93870.

2. WallacelJ.,WorthingtonS., Felson D.T. etal. (2017) Kneeosteoarthritis has doubled in prevalencesince the mid-20th century. Proc. Natl. Acad. Sci. USA, 114: 9332-9336.

3. Castiello E.,AffatatoS. (2020) Progression of osteoarthritis and reoperation in unicompartmental knee arthroplasty: A comparison of national joint registries. Int. J. Art. Org., 43(3): 203-207. doi. org/10.1177/0391398819879697.

4. Costa G.G., Lo Presti M., Grassi A. et al. (2019) Metal-backed tibial components do not reduce risk of early aseptic loosening in unicompartmental knee arthroplasty: a systematic review and meta-analysis. J. Knee Surg. DOl: 10.1055/s-0038-1677506. 
5. Casper D.S., Fleischman A.N., Papas P.V. et al. (2019) Unicompartmental Knee Arthroplasty Provides Significantly Greater Improvement in Function than Total Knee Arthroplasty Despite Equivalent Satisfaction for Isolated Medial Compartment Osteoarthritis. J. Arthroplast., 34(8): 1611-1616. doi. org/10.1016/.jarth.2019.04.005.

6. Longo U.G., Loppini M., Trovato U. et al. (2015) No difference between unicompartmental versus total knee arthroplasty for the management of medial osteoarthtritis of the knee in the same patient: a systematic review and pooling data analysis. Br. Med. Bull., 114(1): 65-73. doi.org/10.1093/bmb/ Idv009.

7. de Jesus C., Stacey D., Dervin G.F. (2017) Evaluation of a Patient Decision Aid for Unicompartmental or Total Knee Arthroplasty for Medial Knee Osteoarthritis. J. Arthroplast., 32(11): 3340-3344. doi. org/10.1016/.jarth.2017.06.014.

8. Deng M., HuY.,ZhangZ. etal. (2021) Unicondylar knee replacement versus total knee replacementfor the treatment of medial knee osteoarthritis: a systematic review and meta-analysis. Arch. Orthopaed. Trauma Surg., 141(8): 1361-1372. doi.org/10.1007/s00402-021-03790-7.

9. Eberbach H., Mehl J., Feucht M.J. et al. (2017) Geometry of the valgus knee: contradicting the dogma of a femoral-based deformity. Am. J. Sports Med., 45:909-914.

10. Siman H., Kamath A.F., Carrillo N. et al. (2017) Unicompartmental Knee Arthroplasty vs Total Knee Arthroplasty for Medial Compartment Arthritis in Patients Older Than 75 Years: Comparable Reoperation, Revision, and Complication Rates. J. Arthroplasty, 32(6): 1792-1797. doi: 10.1016/j. arth.2017.01.020

11. Fabre-AubrespyM.,OllivierM.,PesentiS. etal. (2016) Unicompartmental kneearthroplastyin patients older than 75 results in better clinical outcomes and similar survivorship compared to total knee arthroplasty: a matched controlled study. J. Arthroplasty, 31(12): 2668-2671.

12. Tripathy S.K., Varghese P., Srinivasan A. et al. (2021) Joint awareness after unicompartmental knee arthroplastyand total kneearthroplasty:a systematicreviewand meta-analysis of cohortstudies. Knee surgery, sports traumatology, arthroscopy: official journal of the ESSKA, 29(10): 3478-3487. doi. org/10.1007/500167-020-06327-4.

13. Parisi T.,. Levy D.L., Dennis D.A. etal. (2018) Radiographicchanges in nonoperative contralateral knee after unilateral total knee arthroplasty. J. Arthroplasty, 33:S116-S120.

14. Pfitzner T., Perka C., von Roth P. (2017) AE-Beitrag: unikondylärer ersatz vs. totalendoprothese bei medialer gonarthrose. Z. Orthop. Unfall., 155: 527-533.

15. Huang X., Li H., Chen B. et al. (2021) The incidence and risk factors of contralateral knee arthroplasty after primary unilateral unicompartmental knee arthroplasty. Medicine, 100(32): e26825. doi. org/10.1097/MD.0000000000026825

16. Mohammad H.R., Strickland L., Hamilton T.W. etal. (2018) Long-term outcomes of over 8,000 medial Oxford phase 3 unicompartmental knees — a systematic review. Acta Orthop., 89: 101-107.

17. https://www.nzoa.org.nz/nzod-joint-registry

18. https://ripo.cineca.it/

19. https://ripo.cineca.it/pdf/report_eng_2016.pdf

20. Arirachakaran A., Choowit P., Putananon C. et al. (2015) Is unicompartmental knee arthroplasty (UKA) superior to total knee arthroplasty (TKA)? A systematic review and meta-analysis of randomized controlled trial. Eur. J. Orthop. Surg. Traumatol., 25(5): 799-806. D0l: 10.1007/ s00590-015-1610-9

21. LiddleA.D.,JudgeA.,Pandith.,Murray D.W. (2014) Adverseoutcomes aftertotal and unicompartmental knee replacement in 101330 matched patients: a study of data from the National Joint Registry for England and Wales. Lancet, 384(9952): 1437-1445. doi.org/10.1016/50140-6736(14)60419-0

22. Blevins J.L., Carroll K.M., Burger J.A. et al. (2020) Postoperative outcomes of total knee arthroplasty compared to unicompartmental knee arthroplasty: a matched comparison. Knee 27(2): 565-571. D0l: 10.1016/j.knee.2019.12.005

23. Kleeblad L.J., Borus T.A., Coon T.M. et al. (2018) Midterm survivorship and patient satisfaction of robotic-arm-assisted medial unicompartmental knee arthroplasty: a multicenter study. J. Arthroplasty, 33(6): 1719-1726. DOI: 10.1016/j.arth.2018.01.036

24. Murray D.W.,Parkinson R.W. (2018) Usage of unicompartmental knee arthroplasty. Bone Joint J.,100$B(4): 432-435$.

\footnotetext{
Відомості про авторів:

Жук Петро Михайлович - доктор медичних наук, професор кафедри травматології та ортопедії Вінницького національного медичного університету ім. М.І. Пирогова, Вінниця, Україна. ORCID: 0000-0001-7320-8900

Шаммо Ахмад Мухаммад - аспірант кафедри травматології та ортопедії Вінницького національного медичного університету ім. М.І. Пирогова, Вінниця, Україна.

Мовчанюк Вадим Олегович - аспірант кафедри травматології та ортопедії Вінницького національного медичного університету ім. М.І. Пирогова, Вінниця, Україна.

Адреса для кореспонденції:

Шаммо Ахмад Мухаммад

21018, Вінниця, вул. Пирогова, 56

E-mail:dr.shammo.ahmad@gmail.com
}

25. Clement N.D., Bell A., Simpson P. et al. (2020) Robotic-assisted unicompartmental knee arthroplasty has a greater early functional outcome when compared to manual total knee arthroplasty for isolated medial compartment arthritis. Bone Joint Res., 9(1): 15-22. D0I: 10.1302/2046-3758.91.BJR-2019-0147.R1

26. Kim M.S., Koh I.J., Choi Y.J. et al. (2017) Differences in patient-reported outcomes between unicompartmental and total knee arthroplasties: a propensity score-matched analysis. J. Arthroplasty, 32(5): 1453-1459. D0l: 10.1016/j.arth.2016.11.034

27. Hiyama Y., Wada 0., Nakakita S., Mizuno K. (2016) Joint awareness after total knee arthroplasty is affected by pain and quadriceps strength. Orthop. Traumatol. Surg. Res., 102(4): 435-439. DOI: 10.1016/j.otsr.2016.02.007

28. Vasso M., Del Regno C., D'Amelio A. et al. (2015) Minor varus alignment provides better results than neutral alignment in medial UKA. Knee, 22(2): 117-121. D0I: 10.1016/j. knee.2014.12.004

29. Brown N.M., Sheth N.P., Davis K. et al. (2012) Total knee arthroplasty has higher postoperative morbidity than unicompartmental knee arthroplasty: a multicenter analysis. J. Arthroplast. 27(8 Suppl): 86-90. https://doi.org/10.1016/j.arth.2012.03.022

30. Foran J.R.H., Brown N.M., Valle C.J.D. et al. (2013) Long-term Survivorship and Failure Modes of Unicompartmental Knee Arthroplasty. Clin. Orthop. Relat. Res., 471(1): 102-108. doi: 10.1007/s11999-012-2517-y

31. Newman J.H., Ackroyd C.E., Shah N.A. (1998) Unicompartmental or total knee replacement? Five-year results of a prospective, randomised trial of 102 osteoarthritic knees with unicompartmental arthritis. J. Bone Joint Surg. Br., 80(5): 862-865. doi: 10.1302/0301-620x.80b5.8835

32. Thienpont E., Opsomer G., Koninckx A., Houssiau F. (2014) Joint awareness in different types of knee arthroplasty evaluated with the Forgotten Joint score. J. Arthroplasty, 29(1): 48-51. doi: 10.1016/j.arth.2013.04.024

\section{Differentiated approach in the choice of arthroplasty in medial knee osteoarthritis (literature review)}

\section{P.M. Zhuk, A.M. Shammo, V.o. Movchaniuk}

National Pirogov Memorial Medical University, Vinnytsia, Ukraine

Abstract. Aim: to analyze the advantages and disadvantages of using unicompartmental and total knee replacement in case of medial knee osteoarthritis, to determine the existing differential criteria for choosing the method of arthroplasty, taking into account the individual patient's risk factors. Results. Analysis of data from the modern literature did not allow to determine clear differential criteria for choosing the optimal method of arthroplasty in medial knee osteoarthritis, taking into account the individual patient's risk factors. Unicompartmental knee replacement is associated with better functional outcomes, lower incidence of complications, faster recovery, and greater patient satisfaction. In addition, there are no convincing claims of a statistically significant difference in the frequency of revisions or longevity of implants, which have long been considered significant benefits of total knee replacement. Conclusion. Due to the improvement of surgical techniques and greater availability in the choice of implants, unicompartmental knee replacement has proven to be an effective method of treatment of isolated medial knee osteoarthritis.

Key words: unicompartmental knee replacement, total knee replacement, knee joint, knee osteoarthritis.

\section{Information about the authors:}

Zhuk Petro M. - doctor of medical sciences, professor of the Department of Traumatology and Orthopedics, National Pirogov Memorial Medical University, Vinnytsia, Ukraine. ORCID: 00000001-7320-8900

Shammo Ahmad M. — graduate student of the Department of Traumatology and Orthopedics, National Pirogov Memorial Medical University, Vinnytsia, Ukraine.

Movchaniuk Vadim 0. - graduate student of the Department of Traumatology and Orthopedics, National Pirogov Memorial Medical University, Vinnytsia, Ukraine.

Address for correspondence:

Ahmad Shammo

21018, Vinnytsia, Pirogov str., 56

E-mail:dr.shammo.ahmad@gmail.com 